\title{
Effect of Refrigerant Type and Insulation Thickness on Refrigeration Systems of Land and Sea Vehicles
}

\author{
Ahmet Selim Dalkılıç1,* - Ali Celen ${ }^{1}$ - Alican Çebi ${ }^{1}$ - Somchai Wongwises ${ }^{2}$ \\ 1 Yildiz Technical University Faculty of Mechanical Engineering, Turkey \\ 2 King Mongkut's University of Technology Thonburi, Faculty of Engineering, Thailand
}

\begin{abstract}
Vehicles are used in the transportation industry to carry temperature-sensitive goods. In fact, they are designed to bear away perishable cartage at specific temperatures. In this study, the cold rooms of a frigoship, railroad car and truck were designed in order to store foods. In addition, the effect of refrigerants and insulation thickness of the cold rooms' refrigeration systems were taken into consideration. In the analysis, R12, R22 and their alternatives of R134a and R410A were selected as refrigerants flowing in the cycle. The evaporator capacity, the condenser capacity, the compressor work, the refrigerant flow rate and the coefficient of performance (COP) of the designed refrigeration systems for each vehicle were determined. It was observed that R134a and R410A had a slightly lower COP and required higher compressor work than R12 and R22 for a condensation temperature. Frigoship, truck and railroad car cold rooms working with R12 had COP values of 2.24, 2.63 and 3.17, respectively. Moreover, the proposed refrigerant R134a can be used in applications with its COP values of 2.16, 2.51 and 3.15 for frigoship, truck and railroad cold rooms, respectively. The influence of the insulation thickness of the wall on evaporator capacity was also investigated. It was observed that the cooling load of the frigoship, railroad car and truck cold rooms decreased $69 \%, 68 \%$ and $43 \%$, respectively, with increase of insulation thickness of the wall from $0.03 \mathrm{~m}$ to $0.3 \mathrm{~m}$.
\end{abstract}

Keywords: refrigeration, alternative refrigerants, COP, cold room, insulation, condenser, evaporator

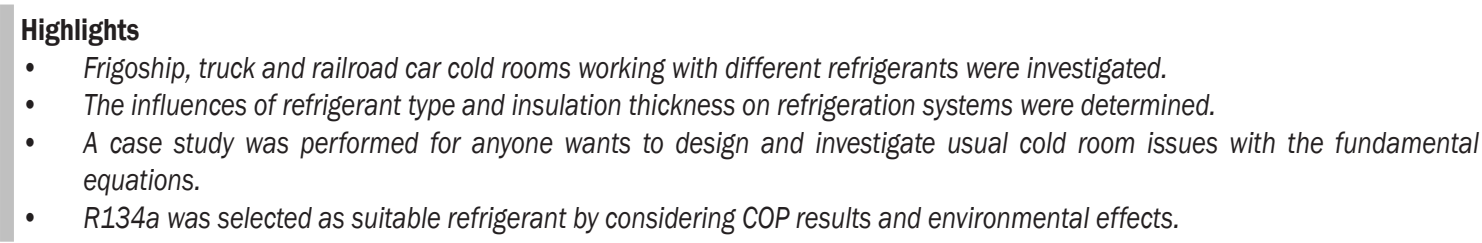

\section{O INTRODUCTION}

Vehicles are commonly used in today's world in order to keep up the quality and increase the shelf life of fresh, perishable and frozen products during transportation. In this refrigeration process, the most important thing is to keep the temperature at the point where metabolic and microbial decompositions are minimized. In other words, designers design for freezing temperatures, which hinder the growth of bacteria. Moreover, designers should pay attention to the details that are necessary during the refrigeration process's design. For instance, which compressor and condenser are correct and convenient for the cold room system should be known. Additionally, efficient cold-storage space, its location with regard to transportation time from the cold room to the market area, product types stored together at the same time, building materials and seasonal temperature changes of the location should be taken into consideration.

Moureh et al. [1] aimed to reduce the temperature differences throughout palletized cargos of perishable products kept in refrigerated vehicles. For this purpose, temperature and ventilation homogeneities were characterized by using air duct systems. Numerical and experimental studies were conducted in order to investigate airflow patterns and temperature levels within a typical loaded vehicle with and without a duct air supply system. The results revealed the importance of air ducts in decreasing temperature differences throughout the cargo.

Tso et al. [2] investigated the usage of an air curtain instead of plasticone in the refrigerated truck application. The usage of a plastic strip curtain can be dangerous because of its design for workers during loading and unloading of products. Experimental results showed that the air curtain, having available volume flow rate and velocity, can block the heat transfer through the door. Further, the infiltration heat load can be reduced $11 \%$ by using an air curtain instead of a plastic strip one.

Hoang et al. [3] modeled heat transfer in a refrigerated vehicle. In the study, they investigated the heterogeneity of product temperature in different loads by considering generally near the rear and front. As a result of their study, CPU computing time was found to be less than $1 \mathrm{~min}$ instead of $60 \mathrm{~h}$ for the same configuration (Moureh et al. [4]). Thus, input parameters could be evaluated rapidly, such as external temperature, door openings, wall insulation, 
thermostat setting, heat of respiration etc., on the load temperatures. Beyond this, the presence of air distribution ducts could be considered, and maximal and minimal load temperature could be predicted. Also, quality and microbiological evolution could be coupled with this approach.

Glouannec et al. [5] experimentally and numerically investigated the thermal properties of an insulation wall by considering the impact of the external environment and durability for refrigerated vans. They aimed to reduce the environmental effects of refrigerated vehicles by improving the insulation design and decreasing energy consumption. Also, the dynamic characterization of the thermal transfer insulation walls was examined. As a result of the study, aerogel and multi-foil insulation layers showed better performance during the daytime period.

Ahmed et al. [6] used phase change materials (PCMs) for refrigerated truck trailer insulation application. Heat and moisture were managed throughout the shipment period to maintain the inside of the truck at a relative humidity and constant temperature. As an analysis of this study, incentive results in lowering peak heat transfer rates and total heat flows into the refrigerated truck trailer were ensured as a heat transfer technology. Accordingly, potentially energy could be saved and pollution from diesel-driven refrigeration equipment was reduced.

Tan et al. [7] analyzed the solidification of phase change material (PCM) and the heat transfer of a cold storage system using tubes to meet the design requirement for the cryogenic energy storage of Liquefied Natural Gas (LNG) refrigerated vehicles. They found as a result of this investigation that the main thermal resistance occurred in the gaseous heat transfer fluid (HTF) inside the tube and the ice layer not only increased radial direction but also propagated it in an axial direction. Further, this study is a good reference for anyone who wants to design and optimize the cold energy storage unit of LNGrefrigerated vehicles.

Cleland [8] demonstrated the significance of refrigerated packaging system design for transportation over important distances. In this study, combining both refrigeration and packaging were taken into consideration and packaging designs for refrigerated food was frequently dictated by the use of low temperature and the high relative humidity conditions. Also, the team that played a role during packaging of perishable food had to balance the needs of marketing staff.

Morganti and Gonzalez-Feliu [9] examined deliveries of perishable goods from the urban distribution center to local food outlets. For this investigation, Parma, Italy, was chosen since it implemented one of the city logistics projects in Europe in order to improve efficiency and reduce the negative effects of urban food distribution within the city. As a result of this study, the delivery schemes for fresh food products adopted by the corporate chain retailers, independent retailers and food services were analyzed. The policy process, the role of the Parma's public authority and the importance of the wholesale produce market as a Food Hub was searched.

Smale et al. [10] studied patterns of airflow using Computational Fluid Dynamics (CFD) in refrigeration systems so that temperature homogeneity could be checked. The conservation of food quality in chilled and frozen food applications was based on controlling of temperature during cooling, storage, transportation and display. The results indicated that the application of airflow modelling techniques enabled ventilation and temperature to be reduced and the efficiency and effectiveness of refrigeration systems to be increased.

Duret et al. [11] focused on temperature and moisture heterogeneity in cold room systems to ensure quality and safety of food products. In their study, a cold room having four apple pallets was observed. A simplified airflow pattern was recommended according to be experimented air velocity field. They tried to clarify heat exchange, water exchanges and airflow mechanisms by measuring velocity of air, temperatures of product and air, convective heat transfer coefficient and weight loss.

Kou et al. [12] wanted to examine temperature variations in refrigerated systems in order to determine their effect on the quality and microbial growth of packaged products. Owing to this research, two commercial open-refrigerated display cases were investigated under different operating conditions using packaged baby spinach products. The results demonstrated that the temperature variation in the cases was dependent on spatial location, thermostat setting, and defrost cycle period and duration of defrost.

In this investigation, the frigoship with $3391 \mathrm{~m}^{3}$ storage volume, the railroad car with $93 \mathrm{~m}^{3}$ storage volume and the truck with $113 \mathrm{~m}^{3}$ storage volume were designed to keep $57,000 \mathrm{~kg}$ of frozen fish, 4,080 $\mathrm{kg}$ of frozen meat and $23,000 \mathrm{~kg}$ of frozen meat, respectively. Main dimensions of the investigated vehicles were given in Table 1 . Frozen fish and meat were kept at $-18{ }^{\circ} \mathrm{C}$ and $-20{ }^{\circ} \mathrm{C}$, respectively. Refrigerant flow rate, condenser capacity, compressor work and coefficient of performance (COP) were figured out for the refrigeration cycle with R12, 
R22 and their alternative refrigerants of R134a and R410A. In addition, effect of insulation thickness on evaporator capacity was detected.

Table 1. Main dimensions of the investigated vehicles

\begin{tabular}{|c|c|c|}
\hline & Specification & Dimension [m] \\
\hline \multirow{8}{*}{ Frigoship } & Length over all & 80.284 \\
\hline & Length of waterline & 78.492 \\
\hline & Rule length & 76.137 \\
\hline & Moulded breadth & 12.500 \\
\hline & Depth & 61.00 \\
\hline & Design draft & 48.00 \\
\hline & Summer draft & 47.47 \\
\hline & Total block coefficient & 8.50 \\
\hline \multirow{6}{*}{ Railroad car } & Height of railroad car & 2.15 \\
\hline & Length of railroad car & 12.78 \\
\hline & Width & 2.6 \\
\hline & Length overall & 14.320 \\
\hline & Height overall & 3.918 \\
\hline & Door size & $2.25 \times 2.59$ \\
\hline \multirow{4}{*}{ Truck } & Length & 13 \\
\hline & Height & 3.20 \\
\hline & Width & 2.70 \\
\hline & Door size & $1.35 \times 3.20$ \\
\hline
\end{tabular}

\section{CALCULATION PROCEDURE}

\subsection{Heat Loss Calculations}

The cooling load of a cold room is determined by summing the heat gained from walls, product, air alteration and heat sources, and it is expressed in Eq. (1). The unknown heat gains were taken into consideration as shown in Eq. (2). A $10 \%$ increase was added to the total value of the system's cooling load, which was equal to the evaporator's heat rejection rate from the cold room.

$$
\begin{gathered}
\dot{Q}_{T}=\dot{Q}_{w}+\dot{Q}_{p}+\dot{Q}_{a}+\dot{Q}_{h}, \\
\dot{Q}_{C L}=\dot{Q}_{\text {evap }}=1.1 \cdot \dot{Q}_{T} .
\end{gathered}
$$

The total heat loss through each wall (such as the ceiling, windows, wall 1 , wall 2 , wall 3 , wall 4 and the floor) can be calculated by means of Eq. (3) as follows:

$$
\dot{Q}_{w}=K_{w} A_{w} \Delta T,
$$

where the temperature difference $(\Delta T)$ was the difference between the inside and neighbor volume temperatures.

$$
\Delta T=T_{\text {out }}-T_{\text {in }} .
$$

The total heat transfer coefficient $\left(K_{w}\right)$ is calculated using Eq. (5) as follows:

$$
\frac{1}{K_{w}}=\frac{1}{h_{i}}+\sum_{i=1}^{n} \frac{L_{i}}{k_{i}}+\frac{1}{h_{o}} \text {. }
$$

The heat transfer rate from the product is estimated as follows:

$$
\begin{gathered}
\dot{Q}_{p}=\left(m_{p} c_{p} \Delta T\right) / t_{\text {cooling }}, \\
\Delta T=T_{p}-T_{i n} .
\end{gathered}
$$

Some amount of heat transfer occurred when the door of the cold room was opened to the outside or a place with a different temperature than the inside of the cold room. This situation brought an additional cooling load to the system, which was calculated as [13]:

$$
\dot{Q}_{a}=H_{d} V\left(h_{n}-h_{i n}\right) \rho_{\text {air }} .
$$

The heat transfer rate from the heat sources (lamps were taken into consideration as heat sources) is determined as follows [13]:

$$
\dot{Q}_{h}=\dot{Q}_{1}=3.6 \cdot n_{1} P_{1} t_{1}
$$

\subsection{Refrigeration Cycle Calculations}

The refrigerant charge rate is calculated as follows:

$$
\dot{m}=\frac{\dot{Q}_{C L}}{h_{1}-h_{4}} .
$$

The condenser capacity and isentropic compression work of the compressor, respectively, are expressed as follows:

$$
\begin{aligned}
& \dot{Q}_{\text {cond }}=\dot{m}\left(h_{2}-h_{3}\right), \\
& W_{\text {comp }}=\dot{m}\left(h_{2}-h_{1}\right) .
\end{aligned}
$$

The COP is used to quantify the performance of refrigeration cycles. It is the ratio of the heat removed from the space to be refrigerated to the work to be consumed to come through this mission. The COP value rises as the power expenditure decreases. It is obvious that this situation will be beneficial to reducing the environmental pollution caused by power production systems. The COP of the refrigeration system's cycle can be determined by the following equation:

$$
C O P=\frac{\dot{Q}_{\text {evap }}}{\dot{W}_{\text {comp }}}
$$




\section{RESULTS AND DISCUSSION}

Freight transportation has increased its importance during the last century. This tendency is anticipated to have nonstop progress in the coming years because of increasing population and demand. According to recent trends in industry, all transportation methods will experience heavy expansion in the world regarding volume, cost, and energy consumption. The parameters of this work influence the cost and energy consumption issues significantly. In addition, the main advantage of this work is to reduce the pollution from diesel-driven refrigeration equipment in investigated vehicles. Lately, ozone depletion potential (ODP) and global warming potential (GWP) have become the most significant criteria in the improvement of novel refrigerants apart from the refrigerant chlorofluorocarbons (CFCs) and hydro chlorofluorocarbons (HCFCs), both of which have high ODP and GWP, owing to the their role in ozone layer depletion and global warming. Despite their high GWP, substitutes to CFCs and HCFCs such as HFC refrigerants with their zero ODP have been favored for practice in many industrial and domestic requests commonly for a decade. HFC refrigerants also have appropriate qualifications, such as non-flammability, stability, and similar vapor pressure to the refrigerants' CFCs and HCFCs.

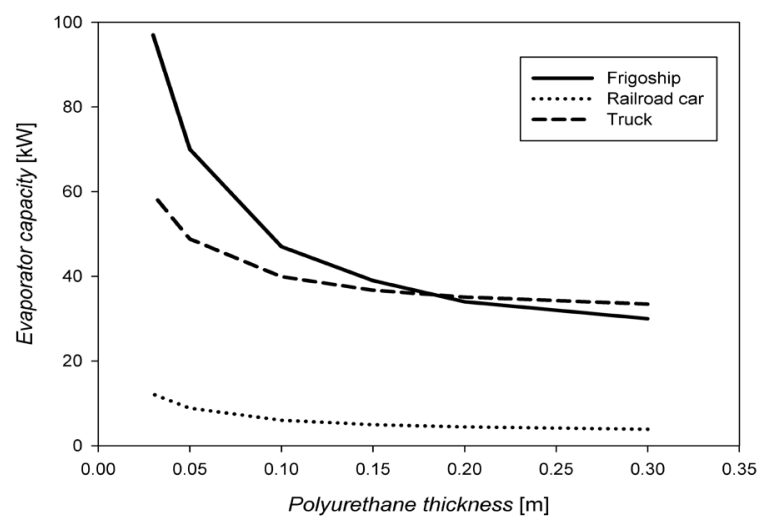

Fig. 1. Variation of evaporator capacity with polyurethane thickness

The refrigeration process is the main process of cold-room systems, which provide proper preservation temperatures to preserve the quality of products. The product is usually a type of perishable food within a certain isolated volume. In addition, many types of medical and perishable products are stored in the same way.
Table 2. The detailed specifications of the cold room construction materials of (a) frigoship, (b) railroad car and (c) truck

\begin{tabular}{|c|c|c|c|c|c|}
\hline \multicolumn{6}{|c|}{ Walls and Ceiling of Frigoship } \\
\hline Material & \multicolumn{2}{|c|}{$\begin{array}{l}\text { Stainless } \\
\text { Steel }\end{array}$} & \multicolumn{2}{|c|}{ Polyurethane } & $\begin{array}{l}\text { Stainless } \\
\text { Steel } \\
\end{array}$ \\
\hline$L[\mathrm{~m}]$ & \multicolumn{2}{|c|}{0.007} & 0.15 & \multicolumn{2}{|c|}{0.007} \\
\hline$k[\mathrm{~W} / \mathrm{mK}]$ & \multicolumn{2}{|l|}{15} & 0.024 & \multicolumn{2}{|r|}{15} \\
\hline$h_{i}\left[\mathrm{~W} / \mathrm{m}^{2} \mathrm{~K}\right]$ & \multicolumn{5}{|c|}{12} \\
\hline$h_{i}\left[\mathrm{~W} / \mathrm{m}^{2} \mathrm{~K}\right]$ & \multicolumn{5}{|c|}{12} \\
\hline$K\left[\mathrm{~W} / \mathrm{m}^{2} \mathrm{~K}\right]$ & \multicolumn{5}{|c|}{0.1558} \\
\hline \multicolumn{6}{|c|}{ Floor of Frigoship } \\
\hline Material & $\begin{array}{c}\text { Stainless } \\
\text { steel }\end{array}$ & $\begin{array}{c}\text { Lean } \\
\text { Concrete }\end{array}$ & $\begin{array}{c}\text { Poly- } \\
\text { styrene }\end{array}$ & $\begin{array}{c}\text { Lean } \\
\text { Concrete }\end{array}$ & Alum \\
\hline$L[\mathrm{~m}]$ & 0.007 & 0.1 & 0.06 & 0.1 & 0.007 \\
\hline$k[\mathrm{~W} / \mathrm{mK}]$ & 0.78 & 1.1 & 0.028 & 1.1 & 1.4 \\
\hline$h_{i}\left[\mathrm{~W} / \mathrm{m}^{2} \mathrm{~K}\right]$ & \multicolumn{5}{|c|}{7} \\
\hline$h_{i}\left[\mathrm{~W} / \mathrm{m}^{2} \mathrm{~K}\right]$ & \multicolumn{5}{|c|}{12} \\
\hline$K\left[\mathrm{~W} / \mathrm{m}^{2} \mathrm{~K}\right]$ & \multicolumn{5}{|c|}{0.3957} \\
\hline \multicolumn{6}{|c|}{ Walls, Ceiling and Floor of Railroad car } \\
\hline Material & $\begin{array}{l}\text { Iron } \\
\text { plate }\end{array}$ & \multicolumn{2}{|c|}{ Wood } & $\begin{array}{l}\text { Poly- } \\
\text { rethane }\end{array}$ & $\begin{array}{c}\text { Stainless } \\
\text { steel }\end{array}$ \\
\hline$L[\mathrm{~m}]$ & 0.01 & \multicolumn{2}{|c|}{0.02} & 0.1 & 0.015 \\
\hline$k[\mathrm{~W} / \mathrm{mK}]$ & 45 & 0.15 & & .024 & 15 \\
\hline$h_{i}\left[\mathrm{~W} / \mathrm{m}^{2} \mathrm{~K}\right]$ & \multicolumn{5}{|c|}{7} \\
\hline$h_{i}\left[\mathrm{~W} / \mathrm{m}^{2} \mathrm{~K}\right]$ & \multicolumn{5}{|c|}{40} \\
\hline$K\left[\mathrm{~W} / \mathrm{m}^{2} \mathrm{~K}\right]$ & \multicolumn{5}{|c|}{0.23} \\
\hline \multicolumn{6}{|c|}{ Walls, Ceiling and Floor of Truck } \\
\hline Material & $\begin{array}{c}\text { Glass Fiber } \\
\text { Reinforced } \\
\text { Polyester }\end{array}$ & $\begin{array}{l}\text { Alum- } \\
\text { inium }\end{array}$ & $\begin{array}{l}\text { Plastic } \\
\text { Foamed }\end{array}$ & $\begin{array}{l}\text { Alum- } \\
\text { inium }\end{array}$ & $\begin{array}{c}\text { Glass Fiber } \\
\text { Reinforced } \\
\text { Polyester }\end{array}$ \\
\hline$L[\mathrm{~m}]$ & 0.005 & 0.005 & 0.15 & 0.005 & 0.005 \\
\hline$k[\mathrm{~W} / \mathrm{mK}]$ & 0.752 & 205 & 0.03 & 205 & 0.03 \\
\hline$h_{i}\left[\mathrm{~W} / \mathrm{m}^{2} \mathrm{~K}\right]$ & \multicolumn{5}{|c|}{7} \\
\hline$h_{i}\left[\mathrm{~W} / \mathrm{m}^{2} \mathrm{~K}\right]$ & \multicolumn{5}{|c|}{40} \\
\hline$K\left[\mathrm{~W} / \mathrm{m}^{2} \mathrm{~K}\right]$ & \multicolumn{5}{|c|}{0.19} \\
\hline
\end{tabular}

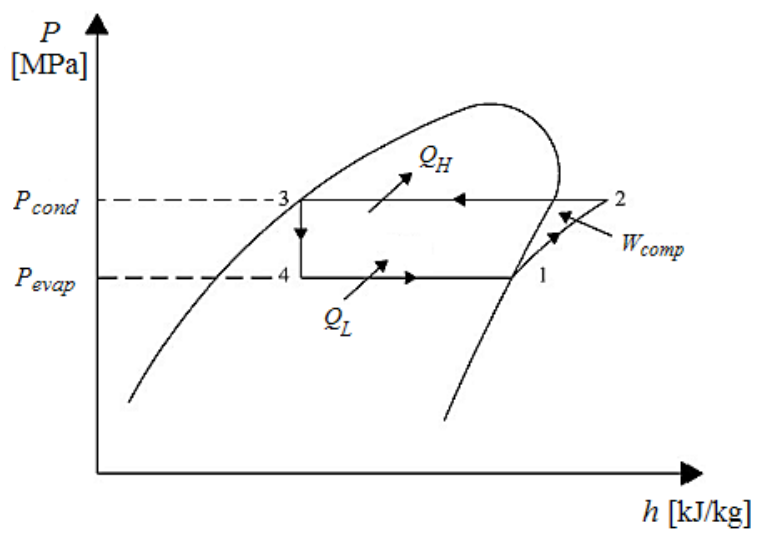

Fig. 2. The ideal vapor-compression refrigeration cycle [20] 


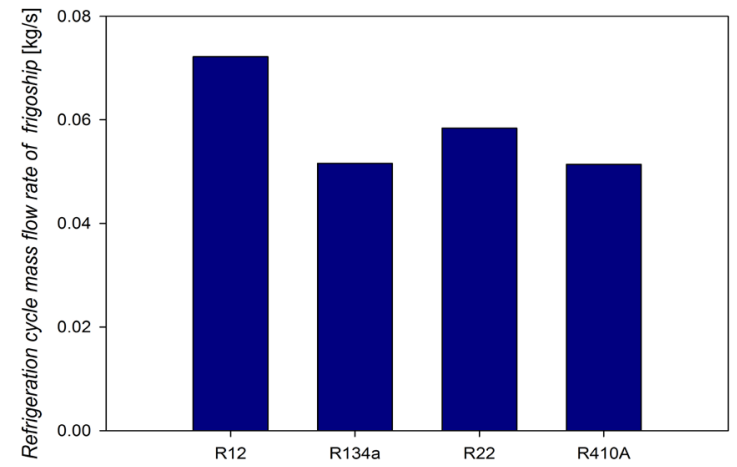

a)

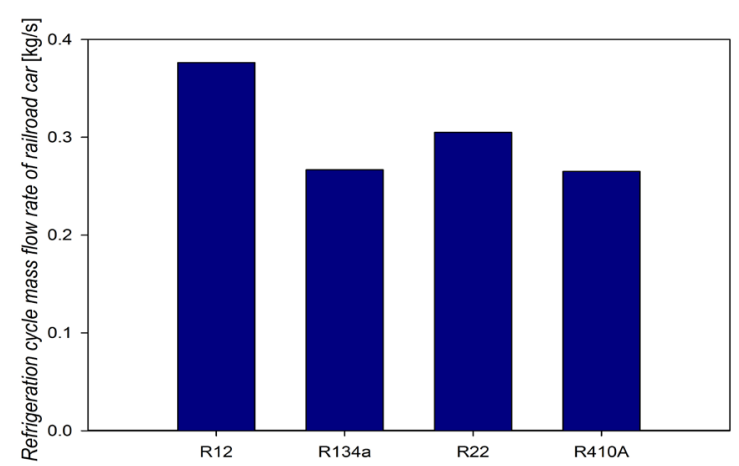

b)

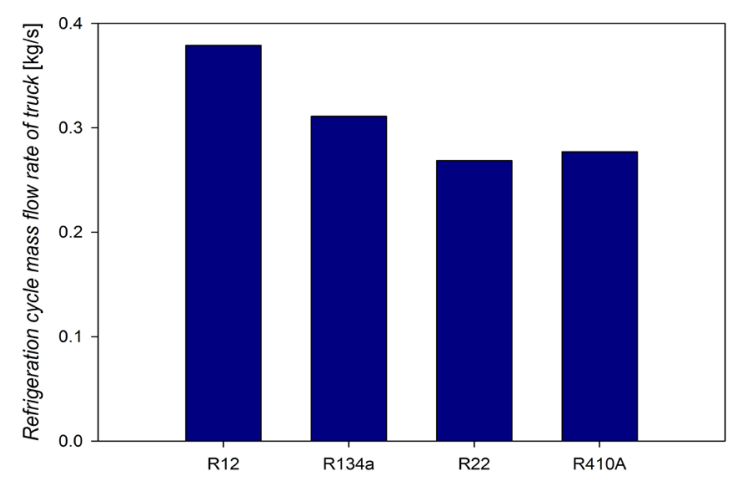

c)

Refrigerant type

Fig. 3. Refrigerant flow rate for different refrigerant types of a) frigoship, b) railroad car and c) truck

Table 3. Variation of evaporator capacity with polyurethane thickness

\begin{tabular}{cccc}
\hline Polyurethane & \multicolumn{3}{c}{$Q_{\text {evap }}[\mathrm{kW}]$} \\
\cline { 2 - 4 } thickness [m] & Frigoship & Railroad car & Truck \\
\hline 0.30 & 30 & 3.87 & 33.43 \\
\hline 0.20 & 34 & 4.42 & 35.09 \\
\hline 0.15 & 39 & 4.96 & 36.72 \\
\hline 0.10 & 47 & 6.00 & 39.90 \\
\hline 0.05 & 70 & 8.85 & 48.81 \\
\hline 0.03 & 97 & 12.14 & 59.35 \\
\hline
\end{tabular}

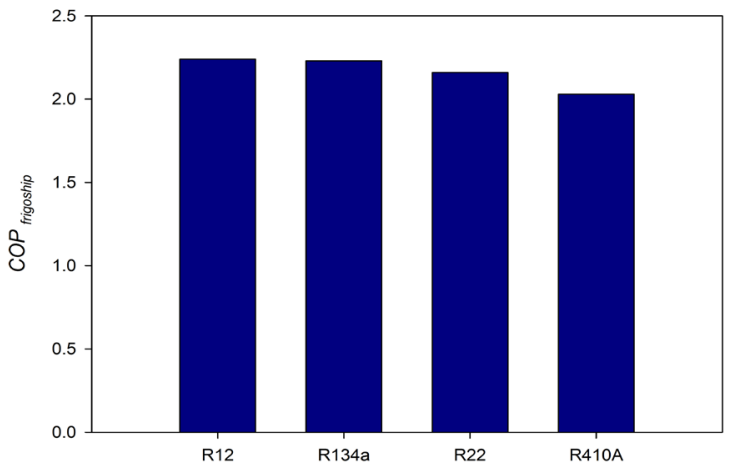

a)

Refrigerant type

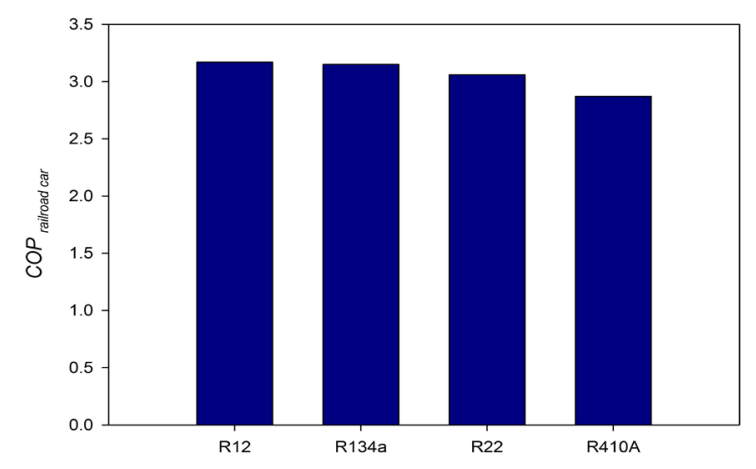

b)

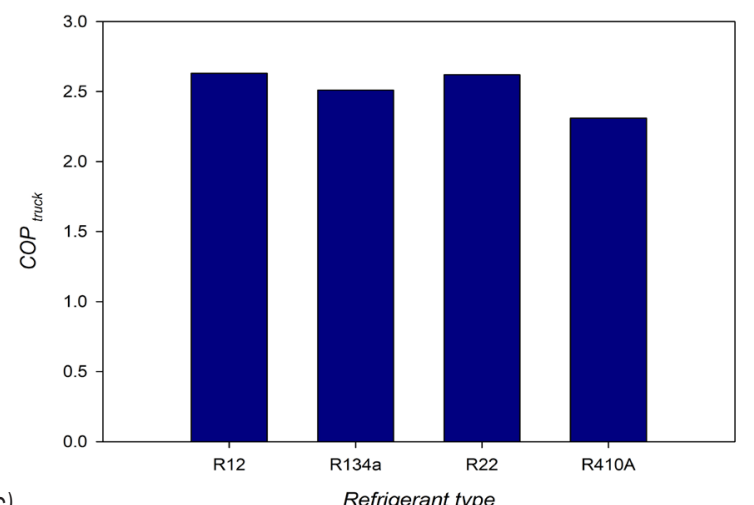

c)

Fig. 4. Variation of COP for different refrigerant type of a) frigoship, b) railroad car and c) truck

Heat transfer rates from the environment are determined by using Eq. (1). Cold rooms' total cooling loads are considered unknown, and heat gain is calculated as $38.73 \mathrm{~kW}, 7.6 \mathrm{~kW}$ and $36.72 \mathrm{~kW}$ for frigoship, railroad car and truck by using Eq. (2), respectively. The total heat loss through each wall is estimated by means of Eq. (3). Total heat transfer coefficients of walls were calculated and given with the details in Table 2. The heat transfer rate from the product, air alteration and lamps are estimated 


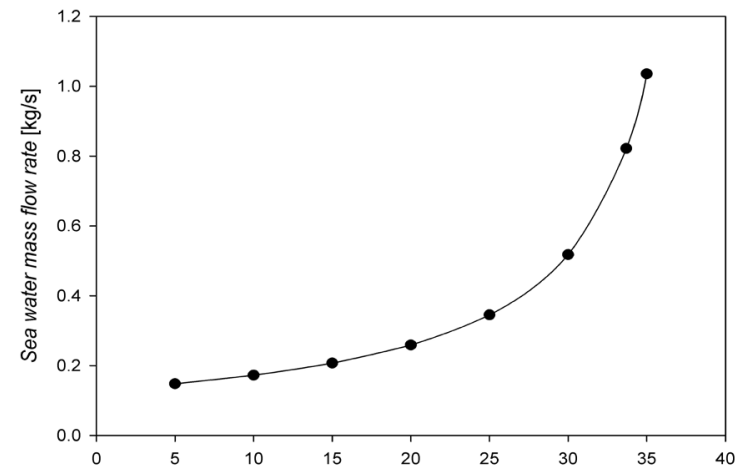

a)

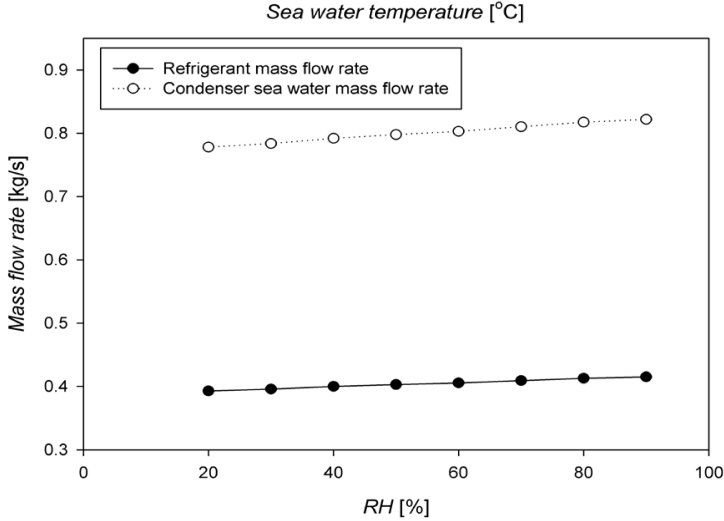

b)

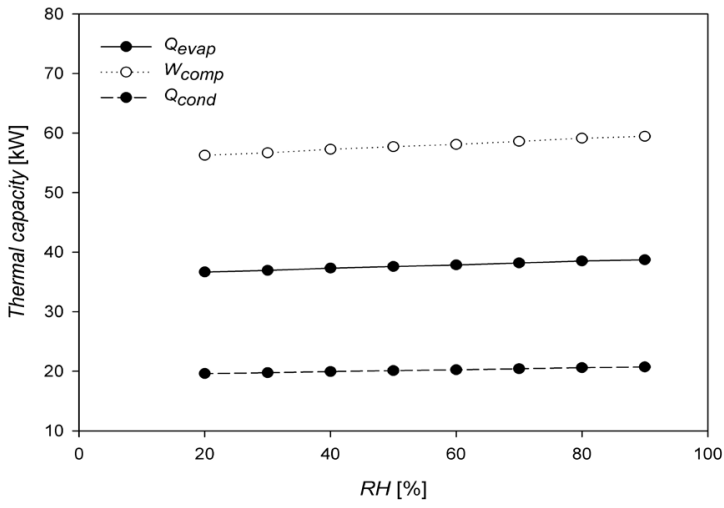

Fig. 5. Variation of mass flow rate of the sea water with sea water temperature a), the refrigerant and sea water mass flow rate with outside relative humidity, b) and the evaporator capacity, the compressor work and the, c) condenser capacity with outside relative humidity

using Eq. (6), Eq. (8) and Eq. (9) for each vehicle, respectively.

It is well known that better insulation results in lower evaporator capacities in cooling applications. Variations of evaporator capacity with polyurethane thickness are given in Table 3 for investigated vehicles. It is found that the evaporator capacity increases as the polyurethane thickness decreases and this is plotted in Fig. 1.
Table 4. The characteristic points enthalpies of different refrigerants used in the cycle

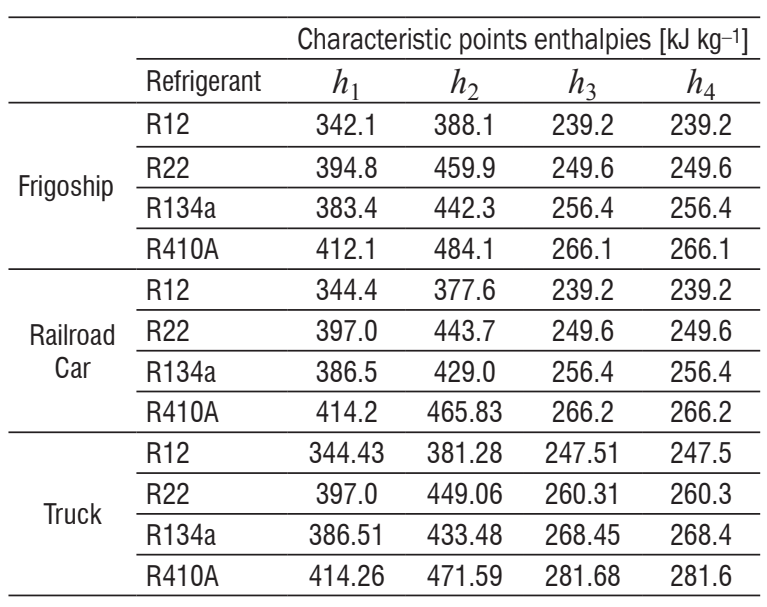

Table 5. Variation refrigerant charge rate, condenser capacity compressor work and COP of different refrigerants for the same evaparator capacity

\begin{tabular}{|c|c|c|c|c|c|}
\hline & Refrigerant & $\begin{array}{c}m \\
{\left[\mathrm{~kg} \mathrm{~s}^{-1}\right]}\end{array}$ & $\begin{array}{l}Q_{\text {evap }} \\
{[\mathrm{kW}]}\end{array}$ & $\begin{array}{c}Q_{\text {cond }} \\
{[\mathrm{kW}]}\end{array}$ & $\begin{array}{c}W_{\text {comp }} \\
{[\mathrm{kW}]}\end{array}$ \\
\hline \multirow{4}{*}{ Frigoship } & R12 & 0.3764 & 38.73 & 17.31 & 56.04 \\
\hline & R22 & 0.2667 & 38.73 & 17.35 & 56.07 \\
\hline & R134a & 0.305 & 38.73 & 17.97 & 56.69 \\
\hline & $\mathrm{R} 410 \mathrm{~A}$ & 0.265 & 38.73 & 19.06 & 57.79 \\
\hline \multirow{4}{*}{$\begin{array}{c}\text { Railroad } \\
\text { Car }\end{array}$} & $\mathrm{R} 12$ & 0.0722 & 7.6 & 9.99 & 2.39 \\
\hline & $\mathrm{R} 22$ & 0.0516 & 7.6 & 10.00 & 2.41 \\
\hline & R134a & 0.0584 & 7.6 & 10.08 & 2.48 \\
\hline & $\mathrm{R} 410 \mathrm{~A}$ & 0.0514 & 7.6 & 10.25 & 2.65 \\
\hline \multirow{4}{*}{ Truck } & $\mathrm{R} 12$ & 0.3789 & 36.72 & 50.68 & 13.96 \\
\hline & R22 & 0.2686 & 36.72 & 50.71 & 13.98 \\
\hline & R134a & 0.3110 & 36.72 & 51.33 & 14.61 \\
\hline & R410A & 0.2770 & 36.72 & 52.60 & 15.88 \\
\hline
\end{tabular}

The ideal refrigeration cycle is shown in Fig. 2 and it is assumed that different refrigerants (R12, $\mathrm{R} 22$, R134a and R410A) are used in the cycle for conditioning cold rooms. In this investigation, Solkane [14] software is used in order to determine the required refrigerant properties. For the ideal cycle, characteristic point enthalpies, which are shown as 1, 2, 3 and 4, are given in Table 4. It should be noted that evaporation temperatures are assumed as $-25{ }^{\circ} \mathrm{C},-20{ }^{\circ} \mathrm{C}$ and $-25{ }^{\circ} \mathrm{C}$ for frigoship, truck and railroad car, respectively. In addition, condensation temperatures are assumed as $10{ }^{\circ} \mathrm{C}, 35^{\circ} \mathrm{C}$ and 48 ${ }^{\circ} \mathrm{C}$, respectively. The refrigerant flow rate, condenser capacity, compressor work and COP are determined by using Eqs. (10) to. (13), respectively, and they are 
shown in Table 5. Refrigerant flow rate and refrigerant type comparison of different refrigerants is given in Fig. 3. It is found that the cycle working with R12 has the highest refrigerant flow rate among the other refrigerant types. COP comparison for different refrigerants is given in Fig. 4. It is found that the cycle working with R12 has the highest COP.

In addition, the variation of the mass flow rate of the sea water with sea water temperatures and the refrigerant and sea water mass flow rates with outside relative humidity were given in Figs. $5 \mathrm{a}$ and $\mathrm{b}$, respectively. Also, the variation of the evaporator capacity, the compressor work and the condenser capacity with outside relative humidity was investigated and shown in Fig. 5c.

It should be noted that additional explanations, figures and tables on the subject exist in authors' previous publications [15] to [20] in the literature. Moreover, it should be known that time dependent local analyses need experimental works as shown in Ahmet et al. [6]. Otherwise, average values of related parameters can be taken from fundamental sources as in this investigation.

\section{CONCLUSION}

In this investigation, cold rooms that are located in the frigoship, railroad car and truck were designed. this is mainly aimed at keeping frozen fish (in frigoship) and meat (in railroad car and truck) at $-18{ }^{\circ} \mathrm{C}$ and $-20{ }^{\circ} \mathrm{C}$, respectively. For this purpose, cold rooms' total heat gain is calculated and the ideal vapor-compression refrigeration cycle calculations were performed for $\mathrm{R} 12, \mathrm{R} 22, \mathrm{R} 134 \mathrm{a}$ and $\mathrm{R} 410 \mathrm{~A}$ refrigerants.

It can be easily determined that polyurethane thickness is a significant parameter for evaporator capacity, so the effect of polyurethane thickness on evaporator capacity was investigated. It was observed that cooling loads of frigoship, railroad car and truck cold rooms decreased from $97 \mathrm{~kW}$ to $30 \mathrm{~kW}$, from $12.14 \mathrm{~kW}$ to $3.87 \mathrm{~kW}$ and from $59.35 \mathrm{~kW}$ to $33.43 \mathrm{~kW}$ with increase of insulation thickness of the wall from $0.03 \mathrm{~m}$ to $0.3 \mathrm{~m}$, respectively.

The refrigerant flow rate, evaporator capacity, condenser capacity, compressor capacity and COP of refrigeration cycle having R12, R22, R134a and $\mathrm{R} 410 \mathrm{~A}$ as working fluid was determined. R12 showed higher COP when they were compared with other refrigerant types. It should be noted that the COP of refrigeration cycles working with R12 was estimated as 2.24, 2.63 and 3.17 for frigoship, truck and railroad cold rooms, respectively. Unfortunately, R12 cannot be used as an alternative refrigerant because of its higher ODP and GWP values. Instead of these refrigerants, their alternatives R134a can be used in the applications with its COP values of 2.16, 2.51 and 3.15 for frigoship, truck and railroad cold rooms, respectively.

\section{ACKNOWLEDGEMENT}

The authors would like to thank the "Research Chair Grant" National Science and Technology Development Agency (NSTDA), the Thailand Research Fund and the National Research University Project (NRU) for the support.

\section{NOMENCLATURES}

A area $\left[\mathrm{m}^{2}\right]$

$C_{p} \quad$ specific heat for the temperature after

freezing process $\left[\mathrm{J} \mathrm{kg}^{-1} \mathrm{~K}^{-1}\right]$

$H_{d} \quad$ air alteration coefficient

$h_{n} \quad$ enthalpy [kJ kg-1]

$h_{\text {in }} \quad$ inside air enthalpy [ $\left.\mathrm{kJ} \mathrm{kg}^{-1}\right]$

$h_{i} \quad$ inner convective heat transfer coefficient $\left[\mathrm{W} \mathrm{m}^{-2} \mathrm{~K}^{-1}\right.$ ]

$h_{o} \quad$ outer convective heat transfer coefficient [W m-2 $\mathrm{K}^{-1}$ ]

$k \quad$ thermal conductivity [W m-2 $\mathrm{K}^{-1}$ ]

$K_{w} \quad$ total heat transfer coefficient $\left[\mathrm{W} \mathrm{m}^{-2} \mathrm{~K}^{-1}\right]$

$L \quad$ length $[\mathrm{m}]$

$l \quad$ freezing heat of product [ $\mathrm{W} \mathrm{kg}^{-1}$ ]

$m \quad$ mass flow rate $\left[\mathrm{kg} \mathrm{s}^{-1}\right]$

$m_{\text {meat }} \quad$ mass of product $[\mathrm{kg}]$

$\mathrm{P}$ heat emitted by lamp $[\mathrm{kW}]$

$Q_{H} \quad$ heat transfer from condenser [kW]

$Q_{L} \quad$ heat transfer from evaporator [kW]

$T$ temperature $\left[{ }^{\circ} \mathrm{C}\right.$ or $\left.\mathrm{K}\right]$

$\Delta T \quad$ temperature difference [K]

$t_{\text {cooling }}$ cooling time [s]

$t_{l} \quad$ working time of lamp [hours/day]

$V \quad$ volume $\left[\mathrm{m}^{3}\right]$

Greek symbol:

$\rho \quad$ density $\left[\mathrm{kg} \mathrm{m}^{-3}\right]$

Subscripts:

a air alteration

ceil ceiling

$C L \quad$ cooling load

comp compressor

cond condensing/condenser

evap evaporating/evaporator

$f \quad$ floor

gen generation 


$\begin{array}{ll}h & \text { heat sources } \\ \text { in } & \text { inside } \\ l & \text { lamp } \\ n & \text { neighbor } \\ \text { out } & \text { outside } \\ p & \text { product } \\ w & \text { wall } \\ T & \text { total }\end{array}$

\section{REFERENCES}

[1] Moureh, J., Menia, N., Flick, D. (2002). Numerical and experimental study of airflow in a typical refrigerated truck configuration loaded with pallets. Computers and Electronics in Agriculture, vol. 34, no. 1-3, p. 25-42, Dol:10.1016/S01681699(01)00178-8.

[2] Tso, C.P., Yu, S.C.M., Poh, H.J., Jolly, P.G. (2002). Experimental study on the heat and mass transfer characteristics in a refrigerated truck. International Journal of Refrigeration, vol. 25, no. 3, p. 340-350, D0l:10.1016/S0140-7007(01)00015-9.

[3] Hoang, M.H., Laguerre, O., Moureh, J., Flick, D. (2012). Heat transfer modelling in a ventilated cavity loaded with food product: Application to a refrigerated vehicle. Journal of Food Engineering, vol. 113, no. 3, p. 389-398, D0l:10.1016/j. jfoodeng.2012.06.020.

[4] Moureh, J., Tapsoba, M.S., Flick, D. (2009). Airflow in a slot-ventilated enclosure partially filled with porous boxes. Part 1 - Measurements and simulations in the clear region. Computers \& Fluids, vol. 38, no. 2, p. 194-205, D0l:10.1016/j. compfluid.2008.02.006.

[5] Glouannec, P., Michel, B., Delamarre, G., Grohens, Y. (2014). Experimental and numerical study of heat transfer across insulation wall of a refrigerated integral panel van. Applied Thermal Engineering, vol. 73, no. 1, p. 194-202, DOl:10.1016/j.applthermaleng.2014.07.044.

[6] Ahmed, M., Meade, O., Medina, M.A. (2010). Reducing heat transfer across the insulated walls of refrigerated truck trailers by the application of phase change materials. Energy Conversation and Management, vol. 51, no. 3, p. 383-392, DOI:10.1016/j.enconman.2009.09.003.

[7] Tan, H., Li, Y., Tuo, H., Zhou, M., Tian, B., (2010). Experimental study on liquid/solid phase change for cold energy storage of liquefied natural gas (LNG) refrigerated vehicle. Energy, vol. 35, no. 5, p. 1927-1935, D0l:10.1016/j.energy.2010.01.006.

[8] Cleland, A.C. (1996). Package design for refrigerated food: The need for multidisciplinary project teams. Trends in Food Science \& Technology, vol. 7, no. 8, p. 269-271, DOI:10.1016/0924-2244(96)20006-8.
[9] Morganti, E., Gonzalez-Feliu, J. (2015). City logistics for perishable products. The case of the Parma's Food Hub. Case Studies on Transport Policy, vol. 3, no. 2, p. 120-129, D0l:10.1016/j.cstp.2014.08.003.

[10] Smale, N. J., Moureh, J., Cortella, G. (2006). A review of numerical models of airflow in refrigerated food applications. International Journal of Refrigeration, vol. 29, no. 6, p. 911930, D0I:10.1016/j.jijrefrig.2006.03.019.

[11] Duret, S., Hoang, H.M., Flick, D., Laguerre, O. (2014). Experimental characterization of airflow, heat and mass transfer in a cold room filled with food products. International Journal of Refrigeration, vol. 46, p. 17-25, Dol:10.1016/j. ijrefrig.2014.07.008.

[12] Kou, L., Luo, Y., Ingram, D.T., Yan, S., Jurick, W.M. (2015). Open-refrigerated retail display case temperature profile and its impact on product quality and microbiota of stored baby spinach. Food Control, vol. 47, p. 686-692, D0l:10.1016/j. foodcont.2014.07.054.

[13] Özkol, N. (1999). Applied Cooling Technology, Chamber of Mechanical Engineers, Istanbul.

[14] SOLKANE (2015). Refrigerant software, version 8. Solvay Fluor GmbH, Hannover.

[15] Dalkilic, A.S., Kürekci, N.A., Kincay, O., Wongwises, S. (2013). Fundamental basis and application for cold-room project design: A Turkish case study. Arabian Journal for Science and Engineering, vol. 38, no. 5, p. 1115-1130, D0l:10.1007/ s13369-012-0534-5.

[16] Dalkilic, A.S., Wongwises, S. (2011). Comparison of various alternative refrigerants for vapour compression refrigeration systems. ASME/JSME $8^{\text {th }}$ Thermal Engineering Joint Conference, p. T10191-T10191-11, Dol:10.1115/ AJTEC2011-44267.

[17] Kaykı, M., Kayaci, N., Celen, A., Dalkilic, A.S., Wongwises, S. (2012). A yacht-type chiller design. ASME 2012 International Mechanical Engineering Congress \& Exposition, p. 15331541, D0I:10.1115/IMECE2012-85736.

[18] Ozturk, M., Goktepe, E., Dalkilic, A.S., Celen, A., Wongwises, S. (2013). Fundamental basis and application of cold-room project design: A case study of fisherman. ASME Summer Heat Transfer Conference.

[19] Alkan, B., Celen, A., Cebi, A., Dalkilic, A.S., Wongwises, S. (2014). Refrigerated railroad car design for shipping frozen meat using alternative refrigerants. ASME Fluids Engineering Summer Meeting, p. V01CT16A002, D0l:10.1115/ FEDSM2014-21068.

[20] Dalkılıç, A.S. (2012). Theoretical analysis on the prediction of coefficient of performance (COP) of vapour compression refrigeration systems using various alternative refrigerants. Journal of Thermal Science and Technology, vol. 32, p. 67-79. 